
ISSN : 2615-1995, E-ISSN : 2615-0654

J. Madani., Vol. 3, No. 2, September 2020 (304 - 318)

(C)2018 Lembaga Kajian Demokrasi

dan Pemberdayaan Masyarakat (LKD-PM)

DOI : https://doi.org/10.33753/madani.v3i2.134

\title{
Preferensi (Komunikasi Pemasaran dan E-Service Quality) Mahasiswa Manajemen Universitas Pamulang Terhadap Pemilihan Situs Belanja Online
}

\author{
Achmad Nur Sholeh \\ Fakultas Ekonomi, Universitas Pamulang \\ dosen01531@unpam.ac.id \\ Arief Budiyanto \\ Fakultas Ekonomi, Universitas Pamulang \\ dosen01433@unpam.ac.id
}

\begin{abstract}
Abstrak
Tujuan dari penelitian ini adalah: (1) Untuk mengetahui pengaruh Komunikasi Pemasaran terhadap Keputusan Pemilihan Situs Belanja Online, (2) Untuk mengetahui pengaruh E-Service Quality terhadap Keputusan Pemilihan Situs Situs Belanja Online dan (3) Untuk Untuk mengetahui pengaruh Komunikasi Pemasaran dan E-Service Quality terhadap Keputusan Pemilihan Situs Situs Belanja Online secara bersama sama. Metode kuantitatif digunakan dalam penelitian ini. Data diambil dari hasil kuesioner yang dikirimkan melalui google form dan juga observasi serta dokumentasi. Jumlah responden yang dijadikan sampel adalah sebanyak 100 responden dengan tehnik simple random sampling sebagai tehnik pengambilan sampel. Analisis data bantuan piranti lunak SPSS 25.0. Hasil uji T (parsial) dan F (simultan) terbukti menunjukkan adanya hubungan yang signifikan antara Komunikasi Pemasaran, E-Kualitas Layanan terhadap Keputusan Mahasiswa dalam Pemilihan Situs Belanja Online.
\end{abstract}

Kata Kunci : Keputusan Pemilihan Konsumen, E-Kualitas Layanan, Komunikasi Pemasaran, Situs Jual Beli Online

\begin{abstract}
The objectives of this study are : (1) To determine the effect of Marketing Communication on Online Purchase Site Selection Decisions, (2) To determine the effect of E-Service Quality on Online Purchase Site Selection Decisions and (3) To determine the effect of Marketing Communication and E-Service Quality on the Decision to Choose Online Purchase Sites collectively. Quantitative methods are used in this research. Data is taken from the results of a questionnaire sent via google form as well as observation and documentation. The number of respondents who were sampled was as many as 100 respondents with simple random sampling technique as a sampling technique. Data analysis assisted by SPSS 25.0 software. T (partial) and F (simultant) test results are proven to show a significant relationship between Marketing Communication, E-Service Quality and Student Decisions in Choosing E-Commerce.
\end{abstract}

Keywords : Consumer Selection Decisions, E-Service Quality, Marketing Communications, E-Commerce

\section{PENDAHULUAN}

Perkembangan TIK (Teknologi, Informasi dan Komunikasi : baca Internet) di Indonesia yang cukup meningkat dalam 5 tahun secara pasti (taken for granted) telah banyak merubah karakter, perilaku maupun budaya yang ada pada masyarakat. Mulai perilaku yang bersifat individu seperti belanja (Muktaf, 2016), belajar 
(Jamun, 2018) dan yang bersifat sosial seperti berkumpul dan lain sebagainya (Setiawan, 2018). Kesemuanya tersebut mengalami perubahan akibat adanya penetrasi internet yang terjadi. Orang mungkin lebih suka untuk belajar dan bersosial secara daring (online) daripada bertatap secara fisik. Begitu juga terkait aktivitas belanja, orang mungkin lebih banyak memanfaatkan aneka kemudahan yang disediakan oleh banyak penyedia loka pasar (marketplace) ataupun yang bersifat perniagaan elektronik (e-commerce).

Berdasarkan kajian yang dirilis oleh Kamar Dagang Australia ((Austrade), 2018) (Australia Government Austrade) dengan mengutip penelitian yang dilakukan oleh Deloitte menunjukkan bahwa 3 (tiga) alasan utama kenapa orang Indonesia memilih belanja secara daring (online) yaitu;

1. Praktis; ketersediaan produk, pengantaran produk dan ketersediaan informasi.

2. Varian Produk; banyaknya varian produk yang bisa ditemukan jika berbelanja secara daring (online).

3. Promosi; Hadiah, poin keanggotaan dan akses anggota ekslusif menjadi salah satu pilihan konsumen Indonesia dalam berbelanja.

Perubahan karakter maupun budaya yang terjadi pada masyarakat tersebut turut juga merubah bagaimana entitas bisnis untuk menyesuaikanpolaperilakuyangadapada masyarakat. Oleh karena itu tidaklah heran jika kemudian banyak pelaku bisnis yang mencoba menawarkan produk/jasanya dengan menggunakan situs (website) jual beli online agar dapat menjangkau masyarakat yang sudah terbiasa dengan internet. Karena dengan memanfaatkan perkembangan TIK (baca : internet); perusahaan dapat mampu bersaing secara kompetitif (E. A. Wibowo, 2016), perusahaan dapat meningkatkan transaksi bisnis dan pertumbuhan ekonomi, (Soegoto \& Rafi, 2018) bahkan dengan memanfaatkan teknologi (internet) perusahaan dapat mampu melayani konsumen dengan cepat serta dapat mengakses pasar global (Rahmidani, 2015).

Dengan semakin banyaknya pelaku bisnis yang memasarkan produknya ke dalam situs daring (website online) memudahkan masyarakat dalam hal ini sebagai konsumen untuk berbelanja menggunakan teknologi internet. Tetapi di satu sisi, dengan banyaknya pilihan yang ada pada masyarakat membuat para pelaku bisnis yang menggunakan internet dituntut untuk memberikan pelayanan prima agar konsumen menggunakan produk/jasa yang dijualnya. Faktor-faktor yang mempengaruhi pemilihan konsumen dalam membeli secara daring (online) antara lain; kepercayaan terhadap situs jual beli dan kemudahan (Wijaya \& Warnadi, 2019), harga dan promosi (Tunnufus, Zakiyya, Wulandari, 2019), serta citra merek (brand image), kualitas website, dan kepercayaan (Adlina et al., 2020).

Diantara situs jual beli yang disukai dan dipilih oleh masyarakat Indonesia berdasarkan situs www.top-brandaward.com periode tahun 20162019 yaitu;

Tabel 1. Daftar Peringkat TBI (Top Brand Indeks) Situs Jual Beli Online
\begin{tabular}{|c|c|c|c|c|}
\hline Peringkat & $\mathbf{2 0 1 6}(\%)$ & $\mathbf{2 0 1 7}(\%)$ & $\mathbf{2 0 1 8}(\%)$ & $\mathbf{2 0 1 9}(\%)$ \\
\hline 1 & $\begin{array}{c}\text { OLX.co.id } \\
(44,5 \%)\end{array}$ & $\begin{array}{c}\text { OLX.co.id } \\
(28,9 \%)\end{array}$ & $\begin{array}{c}\text { Lazada.co.id } \\
(31.8 \%)\end{array}$ & $\begin{array}{c}\text { Lazada.co.id } \\
(31,6 \%)\end{array}$ \\
\hline 2 & $\begin{array}{c}\text { Lazada.co.id } \\
(19,9 \%)\end{array}$ & $\begin{array}{c}\text { Lazada.co.id } \\
(18 \%)\end{array}$ & $\begin{array}{c}\text { Tokopedia. } \\
\text { com }(18,5 \%)\end{array}$ & $\begin{array}{c}\text { Shopee.co.id } \\
(15,6 \%)\end{array}$ \\
\hline 3 & $\begin{array}{c}\text { Tokopedia. } \\
\text { com }(12,1 \%)\end{array}$ & $\begin{array}{c}\text { Tokopedia. } \\
\text { com (13,4\%) }\end{array}$ & $\begin{array}{c}\text { Shopee.co.id } \\
(14,7 \%)\end{array}$ & $\begin{array}{c}\text { Tokopedia. } \\
\text { com }(13,4 \%)\end{array}$ \\
\hline 4 & $\begin{array}{c}\text { Bukalapak. } \\
\text { com (11,8\%) }\end{array}$ & $\begin{array}{c}\text { Bukalapak. } \\
\text { com (6,8\%) }\end{array}$ & $\begin{array}{c}\text { Bukalapak. } \\
\text { com (8,7\%) }\end{array}$ & $\begin{array}{c}\text { Bukalapak. } \\
\text { com (12,7\%) }\end{array}$ \\
\hline 5 & $\begin{array}{c}\text { Elevania.co.id } \\
(1,6 \%)\end{array}$ & $\begin{array}{c}\text { Elevania.co.id } \\
(1,2 \%)\end{array}$ & $\begin{array}{c}\text { Blibli.com } \\
(8 \%)\end{array}$ & $\begin{array}{c}\text { Blibli.com } \\
(6,6 \%)\end{array}$ \\
\hline \multicolumn{5}{|c|}{ Sumber: https://www.topbrand-award.com } \\
\hline
\end{tabular}

Berdasarkan data tabel di atas, perubahan yang terjadi berdasarkan top brand indeks (persepsi merek oleh konsumen - pen) begitu cepat serta signifikan. Itu bisa dilihat pada tahun 2016 dan 2017 dimana peringkat pertama masih diduduki oleh situs olx.co.id tetapi pada tahun 2018 dan 2019 bahkan olx.co.id tidak muncul dalam peringkat 5 besar berdasarkan TBI (top brand indeks). Begitu juga dengan shopee.co.id dan blibli. com dimana pada tahun 2016 dan 2017 tidak termasuk 5 besar TBI (top brand indeks) tapi pada tahun 2018 dan 2019 muncul dalam 5 besar. Selebihnya relatif tidak terlalu signifikan dimana Lazada.co.id yang menempati peringkat 2 pada tahun 2016 dan 2017 naik ke peringkat pertama pada tahun 2018 hingga 2019.

Sedangkan berdasarkan indikator yang ada pada google play store dan apple store berikut peringkat 1-5 situs jual beli pada tahun 2020 . 
Tabel 2. Perbandingan Indikator Aplikasi

Situs Jual Beli Online pada OS Android Tahun 2020

\begin{tabular}{|l|c|c|c|}
\hline \multicolumn{1}{|c|}{ Situs } & Peringkat & Rating Bintang & Jumlah unduhan \\
\hline Shopee.co.id & 1 & $4,6^{*}$ & $50 j t+$ \\
\hline Lazada.co.id & 2 & $4,5^{*}$ & $100 \mathrm{jt} \mathrm{+}$ \\
\hline Tokopedia.com & 3 & $4,5^{*}$ & $50 \mathrm{jt}+$ \\
\hline Bukalapak & 4 & $4,5^{*}$ & $10 \mathrm{jt}+$ \\
\hline Blibli.com & 5 & $4,4^{*}$ & $10 \mathrm{jt}+$ \\
\hline \multicolumn{4}{|c|}{ Sumber: Google Playstore } \\
\hline
\end{tabular}

Tabel 3. Perbandingan Indikator 5 Besar

Aplikasi Situs Jual Beli Online pada OS IOS Tahun 2020

\begin{tabular}{|l|c|c|c|}
\hline \multicolumn{1}{|c|}{ Situs } & Peringkat & Rating Bintang & Jumlah unduhan \\
\hline Shopee.co.id & 1 & $4,7^{*}$ & 273 ribu \\
\hline Lazada.co.id & 2 & $4,8^{*}$ & 250 ribu \\
\hline Tokopedia.com & 3 & $4,8^{*}$ & 221 ribu \\
\hline Bukalapak & 4 & $3,8^{*}$ & 113 ribu \\
\hline Blibli.com & 5 & $4,8^{*}$ & 40,1 ribu \\
\hline \multicolumn{4}{|r}{ Sumber: Apple Store } \\
\hline
\end{tabular}

Secara umum dapat dilihat pada dua tabel perbandingan di atas, peringkat situs jual beli online baik pada operating sistem (OS) berbasis Android maupun Apple tidak berbeda secara urutan. Perbedaan hanya dari sisi jumlah unduhan pengguna. Sedangkan untuk rerata rating bintang dari 5 besar tersebut hanya situs Bukalapak yang mendapatkan angka $3,8^{*}$ (akses medio Juli 2019) sisanya berada di angka 4 dari skala 5 yang bisa dianggap baik oleh konsumen (pengguna).

Akan tetapi peringkat Top Brand Indeks (TBI) beserta jumlah unduhan aplikasi tidak dapat dijadikan acuan dalam melihat banyaknya konsumen yang menggunakan situs jual beli online dalam bertransaksi secara daring (online). Hal tersebut bisa dilihat dari data yang dikeluarkan databoks.katadata.co.id yang mengutip hasil penelitian CLSA sebuah perusahaan investment dari Hongkong, bahwa secara volume transaksi Tokopedia adalah $e$-commerce dengan nilai transaksi paling besar di Indonesia. Berikut data yang ditampilkan oleh databoks.katadata.co.id;

Tabel 4. Nilai Transaksi E-Commerce di Indonesia (dalam USD)
\begin{tabular}{|l|c|c|c|c|}
\hline Situs & $\mathbf{2 0 1 6}$ & $\mathbf{2 0 1 7}$ & $\mathbf{2 0 1 8}$ & $\mathbf{2 0 1 9}$ \\
\hline Tokopedia & 1 miliar & 1,6 miliar & 5,9 miliar & 10,6 miliar \\
\hline Shopee & 300 juta & 1,4 miliar & 3,9 miliar & 7,2 miliar \\
\hline Bukalapak & 575 juta & 920 juta & 1,9 miliar & 3 miliar \\
\hline \multicolumn{5}{|c|}{ Sumber; databoks.katadata.co.id (data diolah) } \\
\hline
\end{tabular}

Data di atas menjadi bisa menjadi sebuah masukan dan alarm bagi para pelaku situs jual beli online. Bahwa jumlah unduhan aplikasi dan tingkat pengenalan merek sebuah situs (yang ditunjukkan oleh TBI) tidak lantas menjadikan e-commerce tersebut menjadi pilihan bagi para konsumen. Bukalapak.com menjadi situs yang menjadi paling menarik jika melihat peringkat dan jumlah unduhan aplikasi pada google play store dan apple store. Walaupun aplikasi yang diunduh hanya 10 juta pengguna pada OS Android dan 113 ribu pada OS IOS tapi secara nilai transaksi bukalapak menempati peringkat 3 besar nasional secara nilai transaksi.

Dalam hal pemilihan situs belanja online, konsumen lebih memilih kemudahan penggunaan dan kepercayaan terhadap situs (website) (Oscar \& Retnoningsih, 2018), (Ardyanto, 2015), Citra merek dan kualitas situs (website) (Adlina et al., 2020) serta kualitas dan kepercayaan terhadap situs (website) (Kurniawan, Kusumawati, \& Priambada, 2018). Pada penelitian yang dilakukan oleh (von Helversen, Abramczuk, Kopeć, \& Nielek, 2018) menunjukkan bahwa konsumen yang membeli secara daring terpengaruh oleh hasil review dan rating tinggi yang diberikan oleh konsumen lainnya.

Melihat kompleksnya preferensi pemilihan situs belanja online serta banyaknya variabel dalam melihat preferensi konsumen memilih situs belanja online, maka dari itu penulis ingin mengajukan penelitian yang berjudul "Preferensi (Komunikasi Pemasaran dan E-Service Quality) Mahasiswa Manajemen Universitas Pamulang Terhadap Pemilihan Situs Belanja Online". Adapun penelitian ini diajukan untuk melihat bagaimana mahasiswa dalam perilaku belanja secara daring dan melihat preferensi apa yang dilihat jika menggunakan situs jual beli online.

\section{Pembatasan Masalah}

Dengan keterbatasan peneliti serta agar lebih mudah di pahami dan dimengerti maka penelitian ini penulis memberikan batasan-batasan yang diteliti, yaitu melihat pengaruh komunikasi pemasaran terhadap keputusan pemilihan mahasiswa dalam memilih situs belanja online, melihat pengaruh e-service quality terhadap keputusan 
pemilihan mahasiswa dalam memilih situs belanja online dan melihat pengaruh komunikasi pemasaran serta e-service quality terhadap keputusan pemilihan mahasiswa dalam memilih situs belanja online secara bersama-sama.

\section{METODE}

\section{Tempat dan Waktu Penelitian}

Objek penelitian dalam penelitian adalah Preferensi Mahasiswa dalam Pemilihan Situs Belanja Daring (online). Waktu penelitian dilakukan mulai dari Januari hingga Juni 2020.

Penelitian ini masuk ke dalam penelitian survei karena informasi yang dikumpulkan menggunakan kuesioner yang disusun secara sistematis dan menggunakan sampel untuk mewakili keseluruhan individu sehingga masuk ke dalam jenis penelitian kuantitatif. Dan bersifat penjelasan (explanatory) karena di akhir analisa penelitian menguji hipotesa.

\section{Populasi}

Populasi dalam penelitian ini adalah mahasiswa Manajemen Aktif yang terdaftar dan berjumlah 21.987 mahasiswa aktif. Dengan pengambilan sampel penelitian sebanyak 100 responden dihitung dengan rumus Slovin dengan MOE (Margin of Error) 10\% serta menggunakan tehnik simple random sampling dalam pengambilan responden. Kuesioner disebar menggunakan google form yang kemudian dijawab oleh responden kemudian diolah untuk dijadikan sebagai dasar perhitungan dalam program SPSS 25.0.

\section{HASIL dan PEMBAHASAN}

\section{Komunikasi Pemasaran Terintegrasi}

(Kotler \& Keller, 2016) mendefinisikan komunikasi pemasaran sebagai alat yang digunakan oleh perusahaan untuk menginformasikan, membujuk dan mengingatkan konsumen baik secara langsung dan tidak langsung tentang produk dan merek yang mereka jual. Konsumen, walaupun sudah mengetahui informasi (well informed) terkadang tidak serta merta memilih dan menggunakan produk/jasa yang dipasarkan oleh perusahaan/pemasar (belum butuh, harga yang terlalu mahal, dan adanya produk sejenis di pasar). Oleh karena itu, perusahaan harus membujuk dan memberikan informasi kepada konsumen untuk membeli dan menggunakan produk/jasa dari perusahaan dan hal tersebut dapat dilakukan melalui komunikasi pemasaran. Dalam pengertian tertentu, komunikasi pemasaran menggambarkan "suara" merek dan merupakan sarana yang dapat digunakannya untuk membangun dialog dan membangun hubungan dengan konsumen.

Hermawan (2012) dalam (Kartika, Hidayat, \& Krinala, 2019) menyatakan bahwa dalam teori marketing communication hubungan antara pemasaran dengan komunikasi merupakan hubungan yang sangat erat. Serta bersifat kompleks tidak sesederhana seperti berbincang-bincang dengan teman atau keluarga.

\section{Indikator Komunikasi Pemasaran (Daring)}

(Tjiptono, 2008) menjelaskan bahwa komunikasi pemasaran merupakan pengembangan dari istilah promosi. Jika promosi bersifat satu arah maka komunikasi pemasaran lebih menenkankan interaksi dua arah yang terjadi antara konsumen dan produsen. Lebih lanjut, (Tjiptono, 2008) menjelaskan komunikasi pemasaran terpadu menekankan dialog teroganisasi dengan audiens (konsumen) internal dan eksternal yang sifatnya lebih personalized, costumer-oriented, dan technology driven.

P.R. Smith dan Zook (2011) dalam (Ikhsana, Prisanto, \& Anggraini, 2019) menjelaskan pengertian IMC (Integrated Marketing Communication) yaitu sebagai bentuk komunikasi pemasaran yang terpadu dalam sebuah organisasi. Lebih lanjut dijelaskan bahwa konsep IMC yang dijelaskan oleh P.R Smith dan Zook (2011) berbeda dengan komunikasi pemasaran yang telah lebih dahulu dijelaskan oleh Kotler dan Keller (2016) perbedaan tersebut terletak pada penambahan 5 (lima) indikator yaitu; pameran (exhibitions), produk yang diperdagangkan (merchandising), kemasaran (packaging), situs (website), media sosial (social media). Sehingga dalam IMC (Integrated Marketing Communication) indikator penilainya antara lain. 
1. Iklan (advertising)

Adalah sebuah bentuk presentasi yang dilakukan oleh bukan orang dengan menggunakan media. Baik media elektronik maupun media cetak.

2. Promosi penjualan (sales promotion) Adalah sebuah insentif langsung yang diberikan kepada produk ataupun jasa untuk mendorong konsumen mencoba produk/jasa yang ditawarkan.

3. Pemasaran Langsung (direct marketing)

Penggunaan media (surat, email, atau internet) ataupun secara langsung berkomunikasi dengan konsumen untuk meminta tanggapan atau berdialog.

4. Hubungan Masyarakat (public relations) Sebuah program komunikasi yang dirancang untuk mempromosikan ataupun melindungi citra perusahaan terhadap tanggapan publik.

5. Acara Khusus (sponsorship).

Kegiatan yang dibiayai dan dirancang untuk menciptakan interaksi dengan merek ataupun produk yang ditawarkan.

6. Pameran (exhibitions)

Pertemuan antara penjual dan pembeli dalam sebuah tempat dalam beberapa hari. Dalam pertemuan tersebut penjual dapat mendemonstrasikan produk/jasa yang ditawarkan dan calon pembeli dapat secara langsung melihat yang ditawarkan.

7. Produkyangdiperdagangkan (merchandising) Sebuah elemen untuk sebuah pasar yang cangkupannya luas mulai dari konsumen hingga industri.

8. Kemasan (packaging)

Sebuah rancangan yang memberikan kesempatan untuk menciptakan keunggulan kompetitif serta menghemat uang.

9. Situs (website)

Adalah sebuah halaman yang menampilkan produk/jasa yang ditawarkan yang umumnya merupakan bagian dari sebuah nama domain atau subdomain pada internet.

10 Media Sosial (social media)

Adalah teknologi berbasis internet yang mengubah komunikasi menjadi sebuah dialog interaksi antar pengguna.

\section{E-Service Quality}

Menurut Zeithaml, dkk (2002) dalam (Ting, Ariff, Zakuan, Sulaiman, \& Saman, 2016) e-service quality adalah metode untuk mengukur sebuah situs website jual beli berdasarkan persepsi pembeli daring tentang seberapa baik sebuah situs memenuhi persyaratan transaksi daring mereka (Ting et al., 2016). Sedangkan menurut (Moon, 2013) yang mengutip juga pendapat Zeithaml, dkk (2005) mendeskripsikan e-service quality sebagai sejauh mana sebuah situs belanja dapat memafasilitasi konsumen dalam belanja, pembelian dan pengiriman produk konsumen secara efektif dan efisien. Lebih lanjut (Moon, 2013) mengutip pendapat Lin (2007) e-service quality mencangkup fungsi layanan tambahan yang berasal dari pasar daring (online), antara lain. Pra penjualan (informasi mengenai produk agar mengurangi biaya pencarian/penelusuran biaya konsumen), pembelian (aktivitas pembelian konsumen) dan setelah pembelian (pengiriman dan problem solving).

(H. A. Wibowo, 2019) menjelaskan bahwa perbedaan antara kualitas layanan yang bersifat konvensional dengan $e$-service quality terletak pada pergantian antara manusia (human) dengan situs (website) sebagai garda depan (front liner) dalam membangun interaksi dengan konsumen maupun calon konsumen. Lebih lanjut dikatakan, hal tersebutlah yang kemudian menjadi alasan bagi para akademisi maupun praktisi mengangkat topik mengenai $e$-service quality pada medio tahun 2000an.

\section{Indikator e-service quality}

Banyak para ahli yang telah mendeskripsikan dan mengemukakan pendapat dan juga berbagai indikator $e$-service quality. Berikut hasil berbagai kajian literasi para ahli mengenai $e$-service quality beserta dimensi pembentuknya menurut $(\mathrm{H}$. A. Wibowo, 2019) yang dirangkum sebagai berikut.

Tabel 5. Skala Pengukuran E-Service Quality Menurut Ahli

\begin{tabular}{|c|c|c|c|c|c|}
\hline \multirow{2}{*}{ No } & Sitequal & Webqual & Etailq & E-S-Qual & E-Recs-Qual \\
\cline { 2 - 6 } & 2001 & 2002 & 2003 & 2005 & 2006 \\
\hline 1 & Ease of use & Useful & $\begin{array}{l}\text { Fulfillment/ } \\
\text { Reliability }\end{array}$ & Efficiency & $\begin{array}{l}\text { Responsive- } \\
\text { ness }\end{array}$ \\
\hline 2 & $\begin{array}{l}\text { Aesthetic } \\
\text { design }\end{array}$ & Ease of use & $\begin{array}{l}\text { Website } \\
\text { design }\end{array}$ & $\begin{array}{l}\text { System avail- } \\
\text { ability }\end{array}$ & $\begin{array}{l}\text { Compensa- } \\
\text { tion }\end{array}$ \\
\hline
\end{tabular}




\begin{tabular}{|c|l|l|l|l|l|}
\hline 3 & $\begin{array}{l}\text { Prosscessing } \\
\text { spedd }\end{array}$ & $\begin{array}{l}\text { Entertain- } \\
\text { ment }\end{array}$ & $\begin{array}{l}\text { Privacy/ } \\
\text { Security }\end{array}$ & Fulfillment & Contact \\
\hline 4 & Security & $\begin{array}{l}\text { Complimen- } \\
\text { tary relation- } \\
\text { ship }\end{array}$ & $\begin{array}{l}\text { Customer } \\
\text { service }\end{array}$ & Privacy & \\
\hline \multicolumn{5}{|c|}{ Sumber : (H. A. Wibowo, 2019) } \\
\hline
\end{tabular}

Keterangan;

- Sitequal; (Yoo and Donthu, 2001)

- Webqual; (Loiacono et al., 2002)

- Etailq; (Wolfinbarger and Gilly, 2003)

- ES-QUAL; (Parasuraman et al., 2005)

- E-RecS-Qual; (Parasuraman et al., 2005)

Menurut (Blut, 2016) indikator untuk melihat e-service quality ada 4 (empat) indikator, yaitu.

a. Website Design (desain situs)

Adalah desain dari situs web, yang mengacu kepada semua elemen yang terkait dengan situs web. Seperti, navigasi, kolom pencarian, pelacakan pesanan, pengiriman, ketersediaan serta penawaran harga produk/jasa.

b. Fulfilment (pemenuhan)

Adalah semua aktivitas yang memastikan bahwa pelanggan menerima apa yang mereka pikir mereka pesan berdasarkan tampilan dan deskripsi yang disediakan di situs dan atau pengiriman produk yang tepat dengan harga yang tepat (harga pengiriman) dan sesuai dengan waktu yang dijanjikan.

c. Costumer Service (layanan pelanggan)

Yaitu layanan yang membantu dan responsif yang menanggapi pertanyaan pelanggan dan menangani pengembalian atau keluhan dengan cepat pada saat penjualan atau setelah penjualan (after sales).

d. Security (keamanan)

Adalah keamanan data atau privasi, yaitu keamanan pembayaran kartu kredit dan privasi informasi bersama selama atau setelah penjualan.

\section{Consumer Decision Online}

(Kotler \& Keller, 2016) mendefinisikan perilaku konsumen sebagai studi tentang bagaimana individu, kelompok, dan organisasi memilih, membeli, menggunakan, dan bagaimana barang, jasa, ide atau pengalaman untuk memuaskan kebutuhan dan keinginan mereka. Sedangkan menurut (Schifmann. Leon dan Kanuk, 2007) perilaku konsumen adalah studi yang terpusat pada cara individu mengambil keputusan untuk memanfaatkan sumber daya mereka yang tersedia (waktu, uang, usaha) guna membeli barangbarang yang berhubungan dengan konsumsi. Hal ini mencakup apa yang mereka beli, mengapa mereka membeli, kapan mereka membeli, dimana mereka membeli, seberapa sering mereka membeli, dan seberapa sering mereka menggunakannya. Lebih lanjut (Schifmann. Leon dan Kanuk, 2007) menerangkan Keputusan Konsumen adalah seleksi terhadap dua pilihan alternatif atau lebih. Dalam proses keputusan, pilihan alternatif harus ada bagi konsumen, jika konsumen tidak mempunyai alternatif untuk memilih dan benarbenar terpaksa melakukan pembelian maka itu bukan disebut dengan keputusan pembelian.

Mutsikiwa dan Marumbwa (2013) dalam (Gunawan, Linawati, Pranandito, \& Kartono, 2019) menjelaskan bahwa banyak faktor yang mempengaruhi keputusan pembelian konsumen, terbagi dalam 3 (tiga) faktor besar,yaitu. Eksternal, Internal dan juga Faktor pemasaran penyedia produk/jasa. Yang termasuk ke dalam faktor eksternal yaitu; budaya, sub budaya, lingkungan dan juga kelas sosial serta keluarga. Sedangkan faktor internal meliputi persepsi, personal (gaya hidup, pendapatan, dll), dan juga sikap. Serta faktor pemasaran penyedia produk/jasa antara lain. Kualitas Produk, kemasan, distribusi produk, layanan dan juga harga.

\section{Indikator Consumer Decision Online}

Menurut (Ardyanto, 2015) yang mengutip pendapat (Devaraj, Fan, \& Kohli, 2003) menerangkan bahwa keputusan pembelian secara daring (online) konsumen dipengaruhi oleh beberapa faktor, antara lain. Efisiensi, Value, dan Interaksi.

a. Efisiensi

Adalah kemudahan dan kecepatan yang didapatkan konsumen ketika melakukan pembelian secara daring (online). Hal tersebut dapat terjadi ketika pra penjualan (promosi, iklan, dsb) ataupun ketika proses pembelian (kemudahan pemesanan, pencarian produk, 
dsb) serta pasca pembelian (pelacakan status pengiriman, dll).

b. Value

Berkenaan dengan segala sesuatu yang ditawarkan oleh penjual baik terkait harga dan juga kualitas produknya. Hal tersebut bisa dinilai dengan harga yang kompetitif serta kualitas produk yang ditawarkan.

c. Interaksi

Segala sesuatu yang dirasakan oleh konsumen dalam melakukan pencarian informasi produk/jasa, pembelian (pencarian produk, harga, dan ketersediaan) serta keamanan dan hubungan dengan layanan pelanggan.

\section{Pembahasan}

Berdasarkan data yang telah dikumpulkan melalui observasi, kuesioner serta review dokumen-dokumen terkait, hasil dari penelitian yang ingin diungkapkan menggunakan gambar oleh peneliti sebagai berikut;

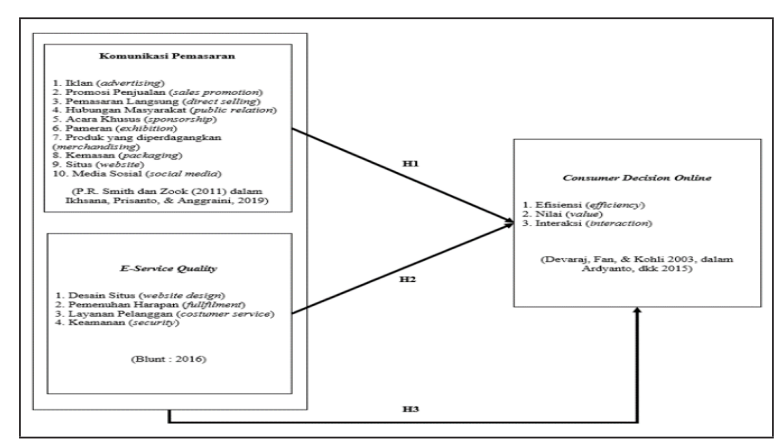

Gambar 1. Model Penelitian

\section{Pembahasan Potret Responden Penelitian}

Berdasarkan hasil dari kuesioner yang telah dihimpun didapatkan karakteristik responden sebagai berikut;

- Dari data 100 responden yang telah dikumpulkan, 49\% berjenis kelamin Laki-laki dan sisanya sebanyak $51 \%$ adalah Perempuan. Dari angka tersebut dapat terlihat dalam penelitian ini tidak didominasi oleh repsonden tertentu. Keduanya hampir berimbang.

- Dominasi umur responden ada pada kategori remaja akhir mendominasi responden yaitu sebanyak 55\% dengan rentang umur 21 tahun s/d 25 tahun, sisanya berimbang antara dewasa awal dan remaja yang masing-masing sebanyak $22 \%$ dan $23 \%$.

- Dan dari segi penghasilan angka responden paling banyak berada pada rentang pendapatan 2,5 juta s/d 5 juta rupiah sebanyak $38 \%$. Sedangkan untuk penghasilan di bawah 1 juta berada pada nomor 2 klasifikasi penghasilan responden yaitu sebanyak $30 \%$.

\begin{tabular}{|c|c|c|c|c|c|c|c|c|c|c|}
\hline \multicolumn{11}{|c|}{ Tabel 6. Analisa Deskriptif Data Responden } \\
\hline No & Pernyataan & $\begin{array}{l}\text { SS } \\
5\end{array}$ & $\begin{array}{l}5 \\
4\end{array}$ & $\begin{array}{c}\text { KS } \\
3\end{array}$ & $\begin{array}{c}\text { TS } \\
2\end{array}$ & $\begin{array}{c}\text { STS } \\
1\end{array}$ & N & Skor & $\begin{array}{l}\text { Rata-rata } \\
\text { Skor }\end{array}$ & $\begin{array}{l}\text { Inter } \\
\text { pretasi }\end{array}$ \\
\hline & \multicolumn{10}{|l|}{ Iklan (Advertising) } \\
\hline \multirow[t]{2}{*}{1} & $\begin{array}{l}\text { Memilih situs belanja online karena } \\
\text { iklan }\end{array}$ & 13 & 49 & 26 & 6 & 6 & 100 & 357 & 3,57 & B \\
\hline & \multicolumn{10}{|l|}{ Promosi (Promotion) } \\
\hline \multirow[t]{2}{*}{2} & $\begin{array}{l}\text { Tertarik situs belanja online karena } \\
\text { promosi penjualan (discount, free } \\
\text { ongkir, poin, dsb) }\end{array}$ & 65 & 30 & 3 & 1 & 1 & 100 & 457 & 4,57 & SB \\
\hline & \multicolumn{10}{|l|}{ Penjualan Langsung (Direct Selling) } \\
\hline \multirow[t]{2}{*}{3} & $\begin{array}{l}\text { Mendapatkan email/notifikasi dari } \\
\text { pihak situs belanja online? }\end{array}$ & 24 & 36 & 31 & 7 & 2 & 100 & 373 & 3,73 & B \\
\hline & \multicolumn{10}{|l|}{ Humas (Public Relations) } \\
\hline \multirow[t]{2}{*}{4} & $\begin{array}{l}\text { Situs belanja online peduli terhadap } \\
\text { konsumen? }\end{array}$ & 28 & 50 & 21 & 1 & 0 & 100 & 405 & 4,05 & SB \\
\hline & \multicolumn{10}{|l|}{ Acara Khusus (Sponshorship) } \\
\hline 5 & $\begin{array}{l}\text { Situs belanja online menjadi sponsor } \\
\text { kegiatan/acara tertentu? }\end{array}$ & 29 & 46 & 21 & 4 & 0 & 100 & 400 & 4,00 & SB \\
\hline
\end{tabular}




\begin{tabular}{|c|c|c|c|c|c|c|c|c|c|c|}
\hline \multirow[b]{2}{*}{6} & \multicolumn{10}{|l|}{ Pameran (Exhibition) } \\
\hline & $\begin{array}{l}\text { Memilih situs belanja online karena } \\
\text { mengadakan pameran? }\end{array}$ & 8 & 34 & 39 & 13 & 0 & 100 & 325 & 3,25 & B \\
\hline & \multicolumn{10}{|l|}{ Barang yang Dijual (Merchandising) } \\
\hline \multirow[t]{2}{*}{7} & $\begin{array}{l}\text { Memilih situs belanja online karena } \\
\text { banyak produknya? }\end{array}$ & 60 & 31 & 8 & 0 & 1 & 100 & 449 & 4,49 & SB \\
\hline & \multicolumn{10}{|l|}{ Kemasan (Packaging) } \\
\hline \multirow[t]{2}{*}{8} & $\begin{array}{l}\text { Memilih situs belanja online karena } \\
\text { keamanan kemasan? }\end{array}$ & 34 & 39 & 26 & 1 & 0 & 100 & 406 & 4,06 & SB \\
\hline & \multicolumn{10}{|l|}{ Situs (Website) } \\
\hline \multirow[t]{2}{*}{9} & $\begin{array}{l}\text { Suka belanja online menggunakan } \\
\text { situs/website komputer bukan aplikasi } \\
\text { smartphone? }\end{array}$ & 7 & 19 & 43 & 12 & 9 & 100 & 283 & 2,83 & $\mathrm{CB}$ \\
\hline & \multicolumn{10}{|l|}{ Media Sosial (Social Media) } \\
\hline 10 & $\begin{array}{l}\text { Bisa berkomunikasi dengan official } \\
\text { sosial media situs belanja online? }\end{array}$ & 33 & 46 & 18 & 2 & 1 & 100 & 408 & 4,08 & SB \\
\hline & Total & 301 & 380 & 236 & 47 & 36 & Total & 3.863 & 3,86 & \\
\hline & $\%$ & 30,10 & 38,00 & 23,60 & 4,70 & 3,60 & - & - & 3,86 & \\
\hline
\end{tabular}

- Berdasarkan data analisa responden di atas untuk variabel Komunikasi Pemasaran $\left(\mathrm{X}_{1}\right)$ terdapat 6 (enam) indikator variabel dengan kategori Sangat Baik (>4.0) dengan indikator Promosi yaitu responden memilih situs belanja online karena adanya promosi dengan nilai skor rata-rata sebesar 4,57.

Tabel 7. Analisa Deskriptif Data Responden

\begin{tabular}{|c|c|c|c|c|c|c|c|c|c|c|}
\hline No & Pernyataan & $\begin{array}{l}\text { SS } \\
5\end{array}$ & $\begin{array}{l}5 \\
4\end{array}$ & $\begin{array}{c}\text { KS } \\
3\end{array}$ & $\begin{array}{c}\text { TS } \\
2\end{array}$ & $\begin{array}{c}\text { STS } \\
1\end{array}$ & $\mathbf{N}$ & Skor & $\begin{array}{l}\text { Rata-rata } \\
\text { Skor }\end{array}$ & $\begin{array}{l}\text { Inter } \\
\text { pretasi }\end{array}$ \\
\hline & Desain Situs (Web Design) & & & & & & & & & \\
\hline 1 & $\begin{array}{l}\text { Memilih situs belanja online karena } \\
\text { tampilan situsnya mudah? }\end{array}$ & 37 & 38 & 5 & 0 & 0 & 100 & 452 & 4,52 & SB \\
\hline 2 & $\begin{array}{l}\text { Memilih situs belanja online karena } \\
\text { situsnya mudah diakses (tidak lemot/ } \\
\text { lambat)? }\end{array}$ & 59 & 35 & 5 & 0 & 1 & 100 & 451 & 4,51 & SB \\
\hline \multicolumn{8}{|c|}{ Skor Indikator } & 903 & 4,52 & \\
\hline & \multicolumn{10}{|l|}{ Pemenuhan Janji (Fullfillment) } \\
\hline 3 & $\begin{array}{l}\text { Memilih situs belanja online karena } \\
\text { produknya sesuai dengan yang } \\
\text { ditampilkan? }\end{array}$ & 39 & 43 & 15 & 2 & 1 & 100 & 417 & 4,17 & SB \\
\hline 4 & $\begin{array}{l}\text { Memilih situs belanja online karena } \\
\text { pengiriman produknya cepat dan } \\
\text { sesuai? }\end{array}$ & 46 & 43 & 10 & 0 & 1 & 100 & 433 & 4,33 & SB \\
\hline & \multicolumn{7}{|c|}{ Skor Indikator } & 850 & 4,25 & \\
\hline & \multicolumn{10}{|l|}{ Keamanan (Security) } \\
\hline 5 & $\begin{array}{l}\text { Memilih situs belanja online karena } \\
\text { layanan pelanggannya proaktif? }\end{array}$ & 36 & 50 & 14 & 0 & 0 & 100 & 422 & 4,22 & SB \\
\hline 6 & $\begin{array}{l}\text { Memilih situs belanja online karena } \\
\text { layanan pelanggannya responsif? }\end{array}$ & 42 & 42 & 14 & 1 & 1 & 100 & 423 & 4,23 & $\mathrm{sB}$ \\
\hline & \multicolumn{7}{|c|}{ Skor Indikator } & 845 & 4,23 & \\
\hline & \multicolumn{10}{|l|}{ Keamanan (Security) } \\
\hline 7 & $\begin{array}{l}\text { Memilih situs belanja online } \\
\text { menyediakan pembayaran non Kartu } \\
\text { Kredit? }\end{array}$ & 43 & 36 & 12 & 4 & 5 & 100 & 408 & 4,08 & SB \\
\hline 8 & $\begin{array}{l}\text { Memilih situs belanja online yang } \\
\text { menyediakan pembayaran di tempat } \\
\text { (COD - Casd On Delivery)? }\end{array}$ & 61 & 24 & 10 & 3 & 2 & 100 & 439 & 4,39 & SB \\
\hline & \multicolumn{7}{|c|}{ Skor Indikator } & 847 & 4,24 & \\
\hline & Total & 383 & 311 & 85 & 10 & 11 & 800 & 3.445 & 4,31 & \\
\hline & $\%$ & 47,88 & 38,88 & 10,63 & 1,25 & 1,38 & - & - & - & \\
\hline
\end{tabular}


- Berdasarkan data analisa responden di atas untuk variabel E-Service Quality $\left(\mathrm{X}_{2}\right)$ semua indikator variabel masuk kategori Sangat Baik (>4.0) dengan indikator Desain Situs (web design) yaitu responden memilih situs belanja online karena tampilan situsnya mudah dengan nilai skor rata-rata sebesar 4,52

\begin{tabular}{|c|c|c|c|c|c|c|c|c|c|c|}
\hline No & Pernyataan & $\begin{array}{l}\text { SS } \\
5\end{array}$ & $\begin{array}{l}5 \\
4\end{array}$ & $\begin{array}{c}\text { KS } \\
3\end{array}$ & $\begin{array}{c}\text { TS } \\
2\end{array}$ & $\begin{array}{c}\text { STS } \\
1\end{array}$ & N & Skor & $\begin{array}{l}\text { Rata-rata } \\
\text { Skor }\end{array}$ & $\begin{array}{l}\text { Inter } \\
\text { pretasi }\end{array}$ \\
\hline & Effisien (Efficiency) & & & & & & & & & \\
\hline 1 & $\begin{array}{l}\text { Memilih situs belanja online karena } \\
\text { mudah mencari produk? }\end{array}$ & 66 & 32 & 2 & 0 & 0 & 100 & 464 & 4,64 & SB \\
\hline 2 & $\begin{array}{l}\text { Memilih situs belanja online karena } \\
\text { lebih menghemat waktu? }\end{array}$ & 69 & 28 & 3 & 0 & 1 & 100 & 466 & 4,66 & SB \\
\hline \multicolumn{8}{|c|}{ Skor Indikator } & 930 & 4,65 & \\
\hline & \multicolumn{10}{|l|}{ Nilai (Value) } \\
\hline 3 & $\begin{array}{l}\text { Memilih situs belanja online karena } \\
\text { harga produknya kompetitif? }\end{array}$ & 66 & 28 & 6 & 0 & 0 & 100 & 460 & 4,60 & SB \\
\hline \multirow[t]{3}{*}{4} & $\begin{array}{l}\text { Memilih situs belanja online karena } \\
\text { produknya berkualitas? }\end{array}$ & 39 & 43 & 16 & 2 & 0 & 100 & 419 & 4,19 & SB \\
\hline & \multicolumn{7}{|c|}{ Skor Indikator } & 879 & 4,40 & \\
\hline & \multicolumn{10}{|l|}{ Interaksi (Interaction) } \\
\hline 5 & $\begin{array}{l}\text { Memilih situs belanja online karena } \\
\text { menyediakan informasi secara } \\
\text { lengkap? }\end{array}$ & 43 & 46 & 11 & 0 & 0 & 100 & 432 & 4,32 & SB \\
\hline 6 & $\begin{array}{l}\text { Memilih situs belanja online karena } \\
\text { keamanan berbelanja? }\end{array}$ & 46 & 39 & 14 & 1 & 0 & 100 & 430 & 4,30 & sB \\
\hline 7 & $\begin{array}{l}\text { Memilih situs belanja online karena } \\
\text { pengiriman yang cepat? }\end{array}$ & 41 & 48 & 10 & 0 & 1 & 100 & 428 & 4,28 & SB \\
\hline \multirow[t]{4}{*}{8} & $\begin{array}{l}\text { Memilih situs belanja online karena } \\
\text { mudah untuk melakukan complain } \\
\text { (keluhan)? }\end{array}$ & 38 & 38 & 18 & 6 & 0 & 100 & 408 & 4,08 & SB \\
\hline & \multicolumn{7}{|c|}{ Skor Indikator } & 1.698 & 4,18 & \\
\hline & Total & 408 & 302 & 80 & 9 & 1 & 800 & 3.507 & 4,41 & \\
\hline & $\%$ & 51,00 & 37,75 & 10,00 & 1,13 & 0,13 & - & - & - & \\
\hline \multicolumn{11}{|c|}{ Sumber : data diolah $(2020)$} \\
\hline
\end{tabular}

- Berdasarkan data analisa responden di atas untuk variabel Keputusan Pemilihan Mahasiswa dalam memilih situs belanja online $\left(\mathrm{Y}_{1}\right)$ semua indikator variabel masuk kategori Sangat Baik (>4.0) dengan indikator Efisiensi (efficiency) yaitu responden memilih situs belanja online karena lebih menghemat waktu dengan nilai skor rata-rata sebesar 4,66

\section{A. Uji Validitas}

Hasil uji validitas untuk mengetahui kesahihan instrument penelitian menunjukkan hasil sebagai berikut.

Kriteria dalam pengujian kesahihan instrument di dalam penelitian ini yaitu dengan cara.

- Jika $\mathrm{r}_{\text {hitung }}<\mathrm{r}_{\text {tabel }}$ dengan taraf 5\% atau nilai Sig $>0,05$ maka butir instrument dinyatakan tidak valid.

- Jika $\mathrm{r}_{\text {hitung }}>\mathrm{r}_{\text {tabel }}$ dengan taraf $5 \%$ atau nilai Sig $<0,05$ maka instrument dinyatakan valid.

\begin{tabular}{|c|c|c|c|c|}
\hline \multicolumn{5}{|c|}{ Tabel 9. Distribusi Jawaban Responden Variabel Y } \\
\hline \multirow{2}{*}{ VARIABEL } & \multirow{2}{*}{$\begin{array}{c}\text { No } \\
\text { Pertanyaan }\end{array}$} & \multicolumn{3}{|c|}{ Perbandingan } \\
\hline & & $r_{\text {hitung }}$ & $r_{\text {tabel }}$ & Keterangan \\
\hline \multirow{10}{*}{$\begin{array}{l}\text { Variabel } X_{1} \\
\text { (Komunikasi } \\
\text { Pemasaran) }\end{array}$} & KOM_1 & 0,588 & 0,1966 & Valid \\
\hline & KOM_2 & 0,402 & 0,1966 & Valid \\
\hline & KOM_3 & 0,586 & 0,1966 & Valid \\
\hline & KOM_4 & 0,555 & 0,1966 & Valid \\
\hline & KOM_5 & 0,645 & 0,1966 & Valid \\
\hline & KOM_6 & 0,708 & 0,1966 & Valid \\
\hline & KOM_7 & 0,506 & 0,1966 & Valid \\
\hline & KOM_8 & 0,564 & 0,1966 & Valid \\
\hline & KOM_9 & 0,539 & 0,1966 & Valid \\
\hline & KOM_10 & 0,623 & 0,1966 & Valid \\
\hline
\end{tabular}




\begin{tabular}{|c|c|c|c|c|}
\hline \multirow{8}{*}{$\begin{array}{l}\text { Variabel } X_{2} \\
\text { (E-Service Quality) }\end{array}$} & E-SQ_1 & 0,633 & 0,1966 & Valid \\
\hline & E-SQ_2 & 0,540 & 0,1966 & Valid \\
\hline & E-SQ_3 & 0,520 & 0,1966 & Valid \\
\hline & E-SQ_4 & 0,749 & 0,1966 & Valid \\
\hline & E-SQ_5 & 0,661 & 0,1966 & Valid \\
\hline & E-SQ_6 & 0,720 & 0,1966 & Valid \\
\hline & E-SQ_7 & 0,624 & 0,1966 & Valid \\
\hline & E-SQ_8 & 0,571 & 0,1966 & Valid \\
\hline \multirow{8}{*}{$\begin{array}{l}\text { Variabel Y1 } \\
\text { (Keputusan } \\
\text { Pemilihan } \\
\text { Konsumen) }\end{array}$} & KEP_1 & 0,584 & 0,1966 & Valid \\
\hline & KEP_2 & 0,563 & 0,1966 & Valid \\
\hline & KEP_3 & 0,635 & 0,1966 & Valid \\
\hline & KEP_4 & 0,741 & 0,1966 & Valid \\
\hline & KEP_5 & 0,820 & 0,1966 & Valid \\
\hline & KEP_6 & 0,807 & 0,1966 & Valid \\
\hline & KEP_7 & 0,708 & 0,1966 & Valid \\
\hline & KEP_8 & 0,635 & 0,1966 & Valid \\
\hline
\end{tabular}

Berdasarkan tabel di atas, menunjukkan semua instrument penelitian dinyatakan sahih atau valid $\left(\mathrm{r}_{\text {hitung }}>\mathrm{r}_{\text {tabel }}\right)$ sehingga penelitian bisa dilanjutkan dengan menggunakan instrument tersebut.

\section{B. Uji Reliabilitas}

Sedangkan hasil Uji Reliabilitas (konsisten/ kehandalan) adalah uji yang digunakan untuk mengetahui sejauh mana instrument yang digunakan dapat dipercaya atau diandalkan. Hasil uji reliabilitas dalam penelitian menunjukkan sebagai berikut:

\begin{tabular}{|l|c|c|c|}
\hline \multicolumn{1}{|c|}{ Tabel 10. Hasil Uji Reliabilitas Instrument Penelitian } \\
\begin{tabular}{|l|c|c|c|}
\hline \multicolumn{1}{|c|}{ Variabel } & $\begin{array}{c}\text { Coeficient } \\
\text { Alpha }\end{array}$ & $\begin{array}{c}\text { Standar } \\
\text { Minimum nilai }\end{array}$ & Keterangan \\
\hline Komunikasi Pemasaran $\left(X_{1}\right)$ & 0,768 & 0,60 & reliable \\
\hline E-Service Quality (X2) & 0,765 & 0,60 & reliable \\
\hline $\begin{array}{l}\text { Keputusan Pemilihan } \\
\text { Konsumen (Y) }\end{array}$ & 0,837 & 0,60 & reliable \\
\hline \multicolumn{4}{|c|}{ Sumber: data olah SPSS 25.0 } \\
\hline
\end{tabular}
\end{tabular}

Berdasarkan tabel di atas, menunjukkan semua instrument penelitian dinyatakan reliable (nilai coefficient alpha $>$ standar nilai minimum) sehingga instrument penelitian dinyatakan reliable dan dapat dipercaya dan diandalkan sebagai instrument penelitian.

\section{Uji Asumsi Klasik \\ 1. Uji Normalitas}

Hasil olah data normalitas pada variabel
X (Komunikasi Pemasaran dan E-Service Quality) terhadap variabel Y (Pemilihan Situs Belanja) adalah sebagai berikut.

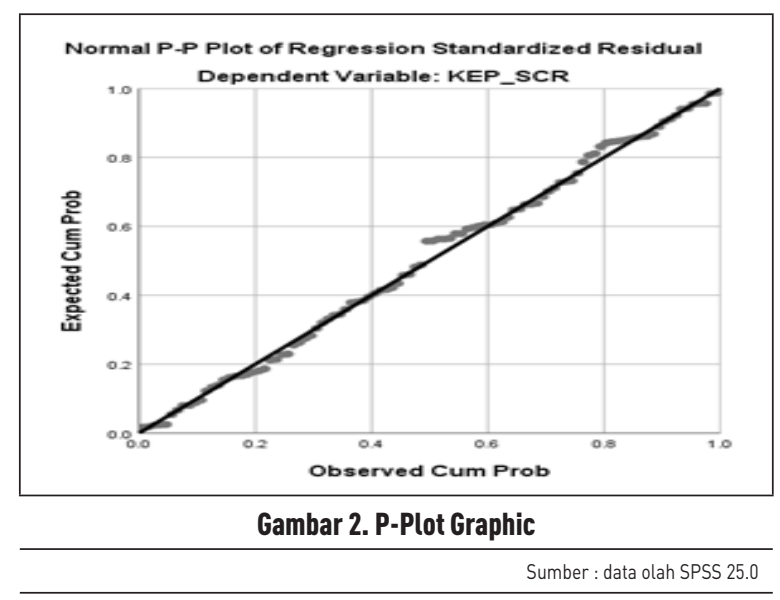

Dari gambar output p-plot di atas dapat disimpulkan bahwa nilai residual terdistribusi secara normal, dimana pada gambar tersebut titik-titik nilai residual yang ada pada tabel alurnya mengikuti garis diagonal yang menunjukkan tingkat normalitas nilai-nilai residual yang ada.

Selain menggunakan hasil output p-plot instrument penelitian ini juga menggunakan uji statistik menggunakan nilai Kolmogorov Smirnov, hal ini dilakukan untuk proses recheck apabila tampilan grafis ataupun lainnya kurang menyakinkan. Kriteria uji normalitas statistik Kolmogorov-Smirnov:

a) Jika nilai Asymp Sig $>0,05$ data terdistribusi normal.

b) Jika nilai Asymp Sig $<0,05$ data tidak terdistribusi normal.

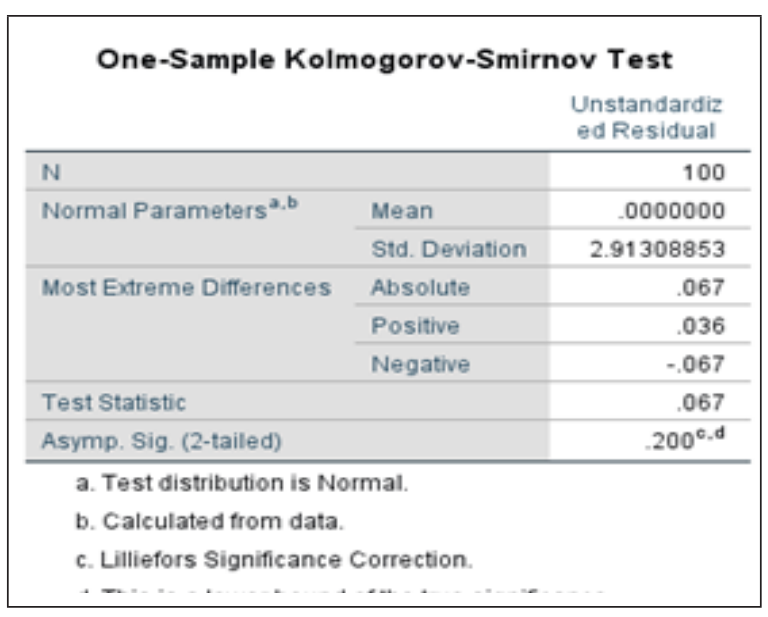

Gambar 3. Nilai Uji Kolmogorov Smirnov 
Dari hasil uji Normalitas dengan metode Kolmogorov-Smirnov di atas, diperoleh besarnya nilai Kolmogorov-Smirnov adalah 0,200 dan nilai Sig 0,05. Nilai signifikansi lebih besar dari 0,05 maka $\mathrm{H}_{0}$ diterima yang berarti data residual berdistribusi normal. Oleh karena itu terpenuhinya asumsi normalitas maka penelitian ini dapat dilanjutkan pada analisis statistik berikutnya

2. Uji Heterokedastisitas

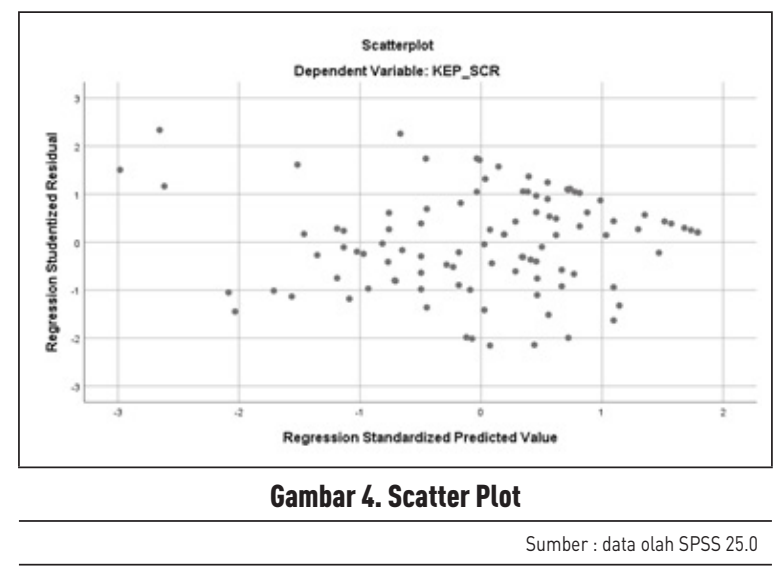

Berdasarkan Grafik di atas, pola titiktitik pada scratter plot menyatakan bahwa regresi menyebar dengan pola tidak jelas dan di bawah angka nol (0) pada sumbu Y maka dalam model regresi ini tidak terjadi masalah heteroskedastisitas.

3. Uji Multikolinearitas

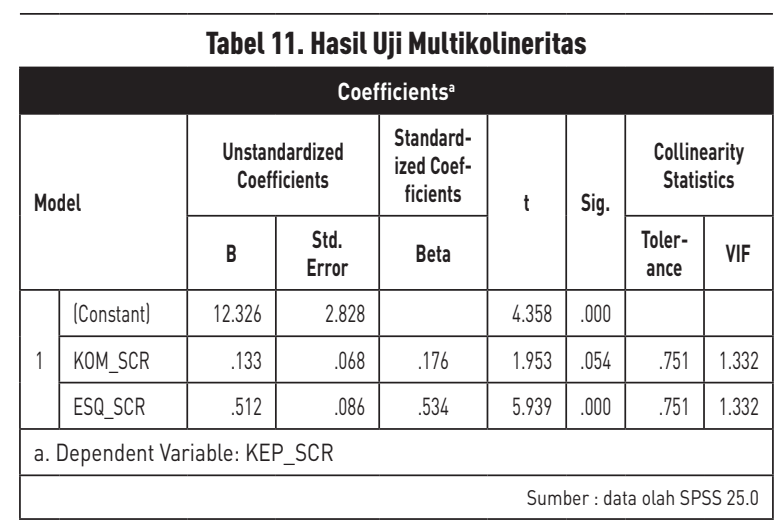

Berdasarkan tabel di atas, pada kolom Tolerance, nilai Tolerance masing-masing variabel bebas: komunikasi pemasaran senilai 0,751 dan e-service quality senilai 0,751. Semua angka tersebut diatas 0,1 .
Sedangkan pada kolom VIF dapat dilihat nilai VIF masing-masing variabel bebas: komunikasi pemasaran senilai 1,322 dan e-service quality senilai 1,322. Nilai VIF dari hasil output SPSS 25.0 tersebut semua di bawah 10. Jadi, dapat disimpulkan bahwa berdasarkan nilai Tolerance yang di atas 0,1 dan VIF dibawah 10, maka dalam penelitian ini tidak terjadi multikoliniearitas.

\section{Uji Hasil Regresi Linier Berganda}

\begin{tabular}{|c|c|c|c|c|c|c|c|c|}
\hline \multicolumn{9}{|c|}{ Tabel 12. Hasil Uji Regresi Lin } \\
\hline \multicolumn{9}{|c|}{ Coefficients $^{\mathrm{a}}$} \\
\hline \multirow{2}{*}{\multicolumn{2}{|c|}{ Model }} & \multicolumn{2}{|c|}{$\begin{array}{l}\text { Unstandardized } \\
\text { Coefficients }\end{array}$} & \multirow{2}{*}{$\begin{array}{c}\begin{array}{c}\text { Standard- } \\
\text { ized Coef- } \\
\text { ficients }\end{array} \\
\text { Beta }\end{array}$} & \multirow{2}{*}{$t$} & \multirow{2}{*}{ Sig. } & \multicolumn{2}{|c|}{$\begin{array}{l}\text { Collinearity } \\
\text { Statistics }\end{array}$} \\
\hline & & B & $\begin{array}{l}\text { Std. } \\
\text { Error }\end{array}$ & & & & $\begin{array}{l}\text { Toler- } \\
\text { ance }\end{array}$ & VIF \\
\hline \multirow{3}{*}{1} & (Constant) & 12.326 & 2.828 & & 4.358 & .000 & & \\
\hline & KOM_SCR & .133 & .068 & .176 & 1.953 & .054 & .751 & 1.332 \\
\hline & ESQ_SCR & .512 & .086 & .534 & 5.939 & .000 & .751 & 1.332 \\
\hline \multicolumn{9}{|c|}{ a. Dependent Variable: KEP_SCR } \\
\hline & & & & & \multicolumn{4}{|c|}{ Sumber : data olah SPSS 25.0} \\
\hline
\end{tabular}

Berdasarkan hasil olah data Regresi di atas bisa disimpulkan bahwa;

$\mathrm{Y}=12,326+0,133 \mathrm{X}_{1}+0,512 \mathrm{X}_{2}$

Interpretasi dari model regresi di atas bisa diartikan sebagai;

a) Nilai constant 12,326 artinya nilai Keputusan pemilihan Mahasiswa dipengaruhi oleh komunikasi pemasaran dan e-service quality sebanyak 12,326 dengan asumsi variabel bebas (X) bernilai tetap.

b) Pengaruh antar variabel

1) Pengaruh komunikasi pemasaran terhadap keputusan pemilihan Mahasiswa adalah positif, artinya setiap kenaikan komunikasi pemasaran akan menaikkan keputusan pemilihan mahasiswa sebanyak 0,133

2) Pengaruh e-service quality terhadap keputusan pemilihan mahasiswa adalah positif, artinya setiap kenaikan e-service quality akan menaikan keputusan pemilihan mahasiswa sebanyak 0,512. 


\section{E. Hasil Uji Korelasi Berganda}

\begin{tabular}{|c|c|c|c|c|c|}
\hline \multicolumn{6}{|c|}{ Tabel 13. Hasil Uji Korelasi Berganda } \\
\hline \multicolumn{6}{|c|}{ Model Summary } \\
\hline Model & R & R Square & $\begin{array}{l}\text { Adjusted } \\
\text { R Square }\end{array}$ & $\begin{array}{l}\text { Std. Error of } \\
\text { the Estimate }\end{array}$ & Durbin-Watson \\
\hline 1 & $.640^{\mathrm{a}}$ & .410 & .398 & 2.943 & 2.023 \\
\hline \multicolumn{6}{|c|}{$\begin{array}{l}\text { a. Predictors: (Constant), ESQ_SCR, KOM_SCR } \\
\text { b. Dependent Variable : KEP_SCR }\end{array}$} \\
\hline \multicolumn{6}{|c|}{ Sumber : data olah SPSS 25.} \\
\hline
\end{tabular}

Berdasarkan tabel hasil analisis korelasi berganda maka diperoleh angka $\mathrm{R}$ sebesar 0,640. Hal ini bisa diartikan bahwa Komunikasi Pemasaran dan E-Service Quality memiliki hubungan yang signifikan dengan Keputusan Pemilihan Situs Belanja Online Mahasiswa, bisa dilihat berdasarkan tabel interval di bawah ini.

\begin{tabular}{|c|c|}
\hline \multicolumn{2}{|c|}{ Tabel 14. Nilai Interval Korelasi } \\
\hline Interval Nilai Koefisien Korelasi & Tingkat Hubungan \\
\hline $0,000-0,199$ & Sangat Rendah \\
\hline $0,200-0,399$ & Rendah \\
\hline $0,400-0,599$ & Sedang \\
\hline $0,600-0,799$ & Kuat \\
\hline $0,800-1,000$ & Sangat Kuat \\
\hline & Sumber : Sugiyono (2015) \\
\hline
\end{tabular}

Angka $\mathrm{R}$ sebesar 0,640 berada pada interval $0,600-0,799$ yang berarti bahwa menunjukkan hubungan korelasi tersebut masuk kategori Kuat.

\section{F. Hasil Uji Koefisien Determinasi}

\begin{tabular}{l}
\hline \multicolumn{7}{|c|}{ Tabel 15. Hasil Uji Koefisien Determinasi } \\
\begin{tabular}{|c|c|c|c|c|c|}
\hline Model Summary \\
\hline 1 & $R$ & R Square & $\begin{array}{c}\text { Adjusted } \\
\text { R Square }\end{array}$ & $\begin{array}{c}\text { Std. Error of } \\
\text { the Estimate }\end{array}$ & Durbin-Watson \\
\hline $\begin{array}{l}\text { a. Predictors: (Constant), ESQ_SCR, KOM_SCR } \\
\text { b. Dependent Variable : KEP_SCR }\end{array}$ & 2.943 & 2.023 \\
\hline \multicolumn{7}{|l|}{} \\
\hline
\end{tabular}
\end{tabular}

Hasil tabel di atas menunjukkan angka $R$ Square sebesar 0,410 yang artinya variabel Komunikasi Pemasaran dan E-Service Quality mempengaruhi terhadap Keputusan Pemilihan Situs Belanja Mahasiwa sebesar $41 \%$ dan sisanya $59 \%$ merupakan sumbangan variabel lain yang tidak diteliti dalam penelitian ini.

\section{G. Hasil Uji Hipotesis}

1. Uji T (parsial)

Uji T (parsial) digunakan untuk mengetahui pengaruh variabel bebas (X) terhadap variabel terikat $(\mathrm{Y})$ secara terpisah,

Hipotesis yang diajukan dalam pengujian pengaruh secara simultan adalah:

$\mathrm{H}_{\mathrm{ol}}$ : Tidak terdapat pengaruh faktor komunikasi pemasaran $\left(\mathrm{X}_{1}\right)$ terhadap keputusan pemilihan situs belanja daring $\left(\mathrm{Y}_{1}\right)$.

$\mathrm{H}_{\mathrm{a} 1}$ : Terdapat pengaruh faktor komunikasi pemasaran $\left(\mathrm{X}_{1}\right)$ terhadap keputusan pemilihan situs belanja daring $\left(\mathrm{Y}_{1}\right)$.

$\mathrm{H}_{\mathrm{o} 2}$ : Tidak terdapat pengaruh faktor e-service quality $\left(\mathrm{X}_{2}\right)$ terhadap keputusan pemilihan situs belanja daring $\left(\mathrm{Y}_{1}\right)$.

$\mathrm{H}_{\mathrm{a} 2}$ : Terdapat pengaruh faktor e-service quality $\left(\mathrm{X}_{2}\right)$ terhadap keputusan pemilihan situs belanja daring $\left(\mathrm{Y}_{1}\right)$.

\begin{tabular}{|c|c|c|c|c|c|}
\hline \multicolumn{6}{|c|}{ Coefficients $^{\mathrm{a}}$} \\
\hline \multirow{2}{*}{ Model } & \multicolumn{2}{|c|}{$\begin{array}{l}\text { Unstandardized } \\
\text { Coefficients }\end{array}$} & \multirow{2}{*}{$\begin{array}{c}\begin{array}{c}\text { Standardized } \\
\text { Coefficients }\end{array} \\
\text { Beta }\end{array}$} & \multirow{2}{*}{$t$} & \\
\hline & B & $\begin{array}{l}\text { Std. } \\
\text { Error }\end{array}$ & & & \\
\hline (Constant) & 22.176 & 2.662 & & 8.331 & .000 \\
\hline KOM_SCR & .334 & . 068 & .442 & 4.885 & .000 \\
\hline
\end{tabular}

Dari hasil pengujian tabel di atas diperoleh $\mathrm{t}_{\text {hitung }}>\mathrm{t}_{\text {tabel }}$ yaitu $4.885>1.984$ yang dapat diartikan bahwa adanya pengaruh Komunikasi Pemasaran $\left(\mathrm{X}_{1}\right)$ terhadap Keputusan Mahasiswa dalam memilih Situs Belanja Online $\left(\mathrm{Y}_{1}\right)$ dan taraf signifikan yang lebih kecil dari $0,05($ sig $<0,05)$ menandakan adanya pengaruh yang signifikan.

Tabel 17. Hasil Uji Parsial Pengaruh Variabel $X_{2}$ Terhadap $Y_{1}$

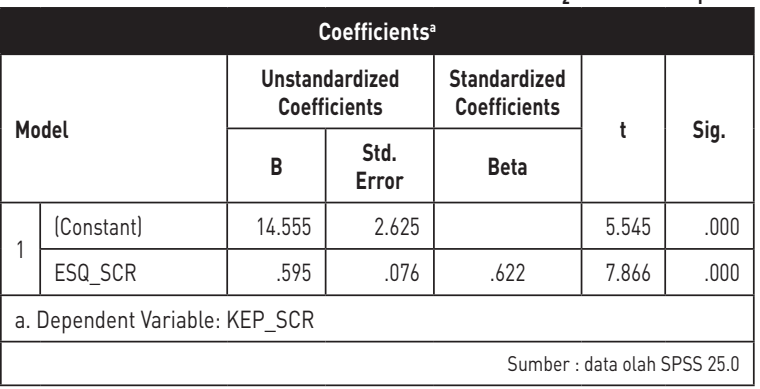

Dari hasil pengujian tabel di atas diperoleh $\mathrm{t}_{\text {hitung }}>\mathrm{t}_{\text {tabel }}$ yaitu $7.866>1.984$ yang dapat diartikan bahwa adanya pengaruh E-Service Quality $\left(\mathrm{X}_{2}\right)$ terhadap Keputusan Mahasiswa 
dalam memilih Situs Jual Beli Online $\left(\mathrm{Y}_{1}\right)$ dan taraf signifikan yang lebih kecil dari 0,05 (sig $<0,05)$ menandakan adanya pengaruh yang signifikan.

2. Uji F (simultan)

Uji F digunakan untuk mengetahui pengaruh variabel bebas $(\mathrm{X})$ secara bersama-sama (simultan) terhadap variabel terikat $(\mathrm{Y})$.

Dengan taraf nyata yang biasa digunakan $5 \%(0,05)$, sedangkan nilai $\mathrm{F}_{\text {tabel }}$ dengan derajat bebas $(\mathrm{db}), \mathrm{V}_{1}=\mathrm{m}-1 ; \mathrm{V}_{2}=\mathrm{n}-\mathrm{m}$

$\mathrm{A}=5 \%$ tingkat signifikansi / tingkat kesalahan

$\mathrm{n} \quad=100$ jumlah sampel

$\mathrm{m}=3$ jumlah variabel

$\mathrm{v}_{1}=\mathrm{m}-1$

$\mathrm{v}_{1}=3-1=2$

$\mathrm{v}_{2}=\mathrm{n}-\mathrm{m}$

$\mathrm{v}_{2}=100-3=97$

$\mathrm{F}_{\text {tabel }}=5 \%, \mathrm{v}_{1}, \mathrm{v}_{2}$

$\mathrm{F}_{\text {tabel }}=5 \%, 2,97$

$\mathrm{F}_{\text {tabel }}=3,09$

- $\mathrm{H}_{\mathrm{o}}$ diterima dan $\mathrm{H}_{\mathrm{a}}$ ditolak jika $\mathrm{F}_{\text {tabel }} \leq$ $\mathrm{F}_{\text {tabel }}$ atau probabilitas Sig $0,000 \geq 0,05$

- $\mathrm{H}_{\mathrm{o}}$ ditolak dan $\mathrm{H}_{\mathrm{a}}$ diterima jika $\mathrm{F}_{\text {hitung }}>$ $\mathrm{F}_{\text {tabel }}$ atau probabilitas Sig 0,000 $<0,05$

Hipotesis yang diajukan dalam pengujian pengaruh secara simultan adalah:

$\mathrm{H}_{03}$ : Tidak terdapat pengaruh faktor komunikasi pemasaran $\left(\mathrm{X}_{1}\right)$ dan e-service quality $\left(\mathrm{X}_{2}\right)$ terhadap keputusan pemilihan situs belanja daring $(\mathrm{Y})$.

$\mathrm{H}_{\mathrm{a}}$ : Terdapat pengaruh faktor komunikasi pemasaran $\left(\mathrm{X}_{1}\right)$ dan e-service quality $\left(\mathrm{X}_{2}\right)$ terhadap keputusan pemilihan situs belanja daring $(\mathrm{Y})$.

\begin{tabular}{|c|c|c|c|c|c|c|}
\hline \multicolumn{7}{|c|}{ Tabel 18. Hasil Uji Simultan Pengaruh Variabel $X_{1}$ dan $X_{2}$ Terhadap $Y_{1}$} \\
\hline \multicolumn{2}{|c|}{ Model } & $\begin{array}{l}\text { Sum of } \\
\text { Squares }\end{array}$ & Df & $\begin{array}{l}\text { Mean } \\
\text { Square }\end{array}$ & $\mathbf{F}$ & Sig. \\
\hline \multirow{3}{*}{1} & Regression & 584.388 & 2 & 292.194 & 33.737 & $.000^{\mathrm{b}}$ \\
\hline & Residual & 840.122 & 97 & 8.661 & & \\
\hline & Total & 1424.510 & 99 & & & \\
\hline \multicolumn{7}{|c|}{$\begin{array}{l}\text { a. Dependent Variable : KEP_SCR } \\
\text { b. Predictors: (Constant), ESQ_SCR, KOM_SCR }\end{array}$} \\
\hline \multicolumn{7}{|c|}{ Sumber : data olah SPSS 25.0} \\
\hline
\end{tabular}

Pada hasil pengujian output SPSS 25.0

Uji F (simultan) di atas diperoleh nilai F yai- tu sebesar 33,737 dengan taraf signifikansi 0,000 . Hal tersebut bisa diartikan bahwa $\mathrm{F}_{\text {hitung }} 33,737>\mathrm{F}_{\text {tabel }} 3,09$ atau probabilitas Sig $0,000<0,05$ maka $\mathrm{H}_{a}$ diterima dan $\mathrm{H}_{\mathrm{o}}$ ditolak yang menunjukkan adanya pengaruh secara simultan antara variabel Komunikasi Pemasaran $\left(\mathrm{X}_{1}\right)$ dan variabel E-Service Quality $\left(\mathrm{X}_{2}\right)$ terhadap variabel Pemilihan Mahasiswa terhadap Situs Belanja Daring (online) $\left(\mathrm{Y}_{1}\right)$.

\section{SIMPULAN}

Uji T (parsial) Komunikasi Pemasaran terhadap Keputusan Mahasiswa dalam memilih Situs Belanja Online. Dari hasil pengujian menggunakan piranti lunak SPSS 25.0 diperoleh $\mathrm{t}_{\text {hitung }}$ $>\mathrm{t}_{\text {tabel }}$ yaitu $4.885>1.984$ yang dapat diartikan bahwa adanya pengaruh Komunikasi Pemasaran $\left(\mathrm{X}_{1}\right)$ terhadap Keputusan Mahasiswa dalam memilih Situs Belanja Online $\left(\mathrm{Y}_{1}\right)$ dan taraf signifikan yang lebih kecil dari 0,05 (sig < 0,05) menandakan adanya pengaruh yang signifikan. Indikator Promosi dengan sub indikator yaitu pemilihan situs belanja karena promosi menjadi sub indikator dengan nilai rata-rata skor paling besar yaitu 4,57 menunjukkan responden dalam memilih situs belanja dikarenakan adanya faktor promosi penjualan yang dilakukan oleh situs belanja online.

Uji T (parsial) E-Service Quality terhadap Keputusan Mahasiswa dalam memilih Situs Belanja Online. Dari hasil pengujian menggunakan piranti lunak SPSS 25.0 diperoleh $\mathrm{t}_{\text {hitung }}>$ $\mathrm{t}_{\text {tabel }}$ yaitu $7.866>1.984$ yang dapat diartikan bahwa adanya pengaruh E-Service Quality $\left(\mathrm{X}_{2}\right)$ terhadap Keputusan Mahasiswa dalam memilih Situs Belanja Online $\left(\mathrm{Y}_{1}\right)$ dan taraf signifikan yang lebih kecil dari 0,05 $($ sig $<0,05)$ menandakan adanya pengaruh yang signifikan. Indikator E-Service Quality dengan sub indikator yaitu pemilihan situs belanja tampilan situs yang mudah menjadi sub indikator dengan nilai rata-rata skor paling besar yaitu 4,52 menunjukkan responden dalam memilih situs belanja dikarenakan tampilan desain situs yang mudah digunakan (user friendly).

Pada hasil pengujian Uji F (simultan) diper- 
oleh nilai F yaitu sebesar 33,737 dengan taraf signifikansi 0,000 . Hal tersebut bisa diartikan bahwa $\mathrm{H}_{\mathrm{a}}$ diterima dan $\mathrm{H}_{\mathrm{o}}$ ditolak yang menunjukkan adanya secara simultan antara variabel Komunikasi Pemasaran $\left(\mathrm{X}_{1}\right)$ dan variabel E-Service Quality $\left(\mathrm{X}_{2}\right)$ terhadap variabel Pemilihan Mahasiswa terhadap Situs Belanja Daring (online) (Y1).

\section{PENGHARGAAN}

Pada kesempatan kali ini penulis ingin mengucapkan terima kasih kepada semua pihak yang terlibat baik secara langsung maupun tidak langsung yang tidak bisa penulis sebutkan satu persatu. Terima kasih atas saran, masukan, dan bantuan, semoga penelitian ini bisa bermanfaat bagi semua pihak

\section{DAFTAR PUSTAKA}

(Austrade), A. T. and I. C. (2018). E-commerce in Indonesia A guide for Australian Business. In Commonwealth of Australia. https://doi. org/10.1094/PDIS-91-9-1198B.

Adlina, F., Ghaisani, P., Purbawati, D., Bisnis, A., Diponegoro, U., City, S., ... Diponegoro, U. (2020). Pengaruh Citra Merek (Brand Image ) Dan Kualitas Website ( Website Quality) Terhadap Keputusan Pembelian ( Purchase Decision ) Melalui Kepercayaan ( E-Trust) Sebagai Variabel Intervening ( Studi Pada Konsumen E-Commerce Zalora . Co . Id Di Kota Semaran. Jurnal Ilmu Administrasi Bisnis, 9.

Ardyanto, D. dkk. (2015). Pengaruh Kemudahan Dan Kepercayaan Menggunakan E-Commerce Terhadap Keputusan Pembelian Online (Survei Pada Konsumen www. petersaysdenim.com). Jurnal Administrasi Bisnis S1 Universitas Brawijaya, 22(1), 01-08.

Blut, M. (2016). E-Service Quality: Development of a Hierarchical Model. Journal of Retailing, 92(4), 500-517. https://doi.org/10.1016/j. jretai.2016.09.002.

Devaraj, S., Fan, M., \& Kohli, R. (2003). E-loyalty: elusive ideal or competitive edge? Communications of the ACM, 46(9), 184. https://doi.org/10.1145/903893.903936.
Gunawan, A. V., Linawati, L., Pranandito, D., \& Kartono, R. (2019). The Determinant Factors of E-Commerce Purchase Decision in Jakarta and Tangerang. Binus Business Review, 10(1), 21. https://doi.org/10.21512/bbr.v10i1.5379.

Ikhsana, P. D., Prisanto, G. F., \& Anggraini, R. (2019). Penerapan Strategi E-Marketing Communication dan Ekuitas Merek Siaranku.Com Terhadap Loyalitas Viewers. Inter Komunika : Jurnal Komunikasi, 4(1), 58. https://doi.org/10.33376/ik.v4i1.217.

Jamun, Y. M. (2018). Dampak Teknologi Terhadap Keluarga. Jurnal Pendidikan dan Kebudayaan Misso, 10(1), 1-136. Retrieved from https:// vinansyahtani.blogspot.com/2013/12/ dampak-teknologi-terhadap-keluarga.html.

Kartika, C., Hidayat, F., \& Krinala, E. (2019). Pengaruh Relationship Marketing, Komunikasi Pemasaran dan Citra Perusahaan Terhadap Niat Perilaku Konsumen Melalui Kepuasan Pelanggan Pada Vasa Hotel Surabaya. JMM17: Jurnal Ilmu Ekonomi dan Manajemen, 6(02), 1-14. https://doi. org/10.30996/jmm.v6i02.2992.

Kotler, P., \& Keller, K. L. (2016). Marketing Management Global Edition (Vol. 15E). https://doi.org/10.1080/08911760903022556.

Kurniawan, R., Kusumawati, A., \& Priambada, S. (2018). Pengaruh Kualitas Website (Webqual) Terhadap Kepercayaan Dan Dampaknya Pada Keputusan Pembelian Pada Website E-Commerce (Studi pada Konsumen PT . B) Jurnal Administrasi Bisnis, 62(1), 198-206.

Moon, Y. J. (2013). The Tangibility and Intangibility of e-Service Quality. 7(5), 91-102.

Muktaf, Z. M. (2016). E commerce sebagai Agen Konsumsi di Era Media Baru. International Conference Social Politic Universitas Muhamadiyah Yogyakarta, 26-28.

Oscar, D., \& Retnoningsih, E. (2018). Kemudahan dan Kepercayaan Menggunakan E-Commerce Berpengaruh Terhadap Keputusan Dalam Pembelian Online dengan Metode Technology Acceptance Model. Indonesian Journal on Software Engineering (IJSE), 4(1), 67-72. https://doi.org/10.31294/ ijse.v4i1.6299. 
Rahmidani, R. (2015). Penggunaan E-Commerce Dalam Bisnis Sebagai Sumber Keunggulan Bersaing Perusahaan. Penggunaan E-Commerce Dalam Bisnis Sebagai Sumber Keunggulan Bersaing Perusahaan, (c), 345352. Retrieved from http://fe.unp.ac.id/sites/ default/files/unggahan/26. Rose Rahmidani (hal 344-352)_0.pdf.

Schifmann. Leon dan Kanuk, L. L. (2007). Perilaku Konsumen (Alih bahas). Jakarta: PT. Indeks.

Setiawan, D. (2018). Dampak Perkembangan Teknologi Informasi dan Komunikasi Terhadap Budaya. JURNAL SIMBOLIKA: Research and Learning in Communication Study, 4(1), 62. https://doi.org/10.31289/ simbollika.v4i1.1474.

Soegoto, E. S., \& Rafi, M. S. F. (2018). Internet role in improving business transaction. IOP Conference Series: Materials Science and Engineering, 407(1). https://doi. org/10.1088/1757-899X/407/1/012059.

Ting, O. S., Ariff, M. S. M., Zakuan, N., Sulaiman, Z., \& Saman, M. Z. M. (2016). E-Service Quality, E-Satisfaction and E-Loyalty of Online Shoppers in Business to Consumer Market; Evidence form Malaysia. IOP Conference Series: Materials Science and Engineering, 131(1). https://doi. org/10.1088/1757-899X/131/1/012012.

Tjiptono, F. dkk. (2008). Pemasaran Strategik.
Yogyakarta: Penerbit Andi.

Tunnufus, Zakiyya, Wulandari, A. (2019). Pengaruh Harga dan Jenis Media Promosi Terhadap Keputusan Pembelian Online Pada E-Commerce Shopee di Kabupaten Lebak. The Asia Pacific; Journal of Management Studies, 6(1), 29-40. https://doi.org/10.1016/j. fopow.2017.08.035.

von Helversen, B., Abramczuk, K., Kopeć, W., \& Nielek, R. (2018). Influence of consumer reviews on online purchasing decisions in older and younger adults. Decision Support Systems, 113(March), 1-10. https://doi. org/10.1016/j.dss.2018.05.006.

Wibowo, E. A. (2016). Pemanfaatan Teknologi E-Commerce Dalam Proses Bisnis. Equilibiria, 1(1), 95-108. Retrieved from http://journal.unrika.ac.id/index.php/equi/ article/view/222.

Wibowo, H. A. (2019). The mediating role of e-satisfaction on the effect of e-service quality dimensions on e-loyalty: A lesson from Bukalapak.com Indonesia. Humanities and Social Sciences Letters, 7(4), 199-203. https://doi.org/10.18488/ journal.73.2019.74.199.208.

Wijaya, E., \& Warnadi. (2019). Factors Affecting Online Purchase Decisions At Shopee: Effect of E-Commerce. Procuratio: Jurnal Ilmiah Manajemen, 7(2), 152-164. 